\title{
Health services research in colorectal cancer: a quasi-experimental interventional pilot study on in- and outpatient oncology
}

\author{
Margarete Reiter ${ }^{1,2}\left(\right.$ Michael Gerken $^{3} \cdot$ Patricia Lindberg-Scharf $^{4} \cdot$ Alois Fuerst $^{5} \cdot$ Gudrun Liebig-Hörl $^{6}$. \\ Olaf Ortmann ${ }^{7} \cdot$ Ingeborg Eberl $^{8} \cdot$ Sabine Bartholomeyczik $^{9}$
}

Received: 20 February 2020 / Accepted: 5 November 2020 / Published online: 29 December 2020

(c) The Author(s) 2020

\begin{abstract}
Introduction Due to frequent treatment side effects and weight loss, colorectal cancer patients require oncologic care and nutritional counseling both during and after hospitalization. The current study evaluated differences in discharge and side effects management and nutritional behavior between colorectal cancer patients of a control group without systematic counseling and of an intervention group with access to structured in- and outpatient oncology nurse and nutritional counseling. Methods The presented explorative, quantitative, single-center, interventional pilot study is a health services research project with a quasi-experimental design. Using a self-designed standardized questionnaire, data were collected from the control group $(n=75)$ before and from the intervention group $(n=114)$ after the introduction of in- and outpatient oncology nurse and structured systematic nutritional counseling. The in- and outpatient counseling services were developed and evaluated in the form of a structured nurse-led counseling concept.

Results Intervention group patients profited significantly from inpatient oncology nurse counseling in seven different areas of discharge management. No differences were observed concerning patient-reported general and gastrointestinal side effects except for xerostomia and dysphagia, but of the patients participating in both in- and outpatient oncology nurse counseling, 90.0\% were better able to cope with general side effects of treatment. Patients with in- and outpatient structured systematic nutritional counseling more frequently received nutritional information $(p=0.001)$, were better at gauging food intolerances $(p=0.023)$, and followed the dietician's advice in cases of gastrointestinal side effects significantly more often $(p=0.003)$ than control patients. Counselor-reported outcomes concerning gastrointestinal side effects showed improvement in most of the patients taking part in systematic in- and outpatient nutritional counseling, except for weight loss in 4 patients.

Conclusion In- and outpatient counseling in discharge and side effects management and nutrition improve the outcomes of colorectal cancer patients. Outpatient counseling should be further developed and evaluated in future studies.
\end{abstract}

Keywords Health services research · Colorectal cancer · Drug-related side effects and adverse reactions · Oncology nurse counseling $\cdot$ Nutritional counseling

\section{Introduction}

With almost 59,000 new cases each year, colorectal cancer is the second most common malignant disease in Germany (Robert-Koch-Institut 2017). Patients frequently lose 5-10\% of their body weight within 2-3 months, and suffer from various adverse physical and psychological effects of (neo)adjuvant radio-/chemotherapy such as appetite loss, nausea and vomiting, abdominal pain, diarrhea, constipation, flatulence,

Margarete Reiter

Margarete.Reiter@t-online.de

Extended author information available on the last page of the article mucositis, dysosmia, dysgeusia, difficulty chewing, xerostomia, hand-foot syndrome, sleep disorders, fatigue syndrome, and anxiety and depression (Kreitler 2019; Adlard et al. 2016; Van Vulpen et al. 2016; Middleton 2014; Anderson et al. 2013; Ravasco et al. 2012; Hartinger et al. 2012).

Colorectal cancer patients require professional help to develop self-management strategies to deal with anxiety and insecurity (Appleton et al. 2018) and disease-/treatmentrelated symptoms (Anderson et al. 2013). They require qualified counseling to stabilize their body weight through sufficient intake of energy and protein (Arends et al. 2017) and also to guide physical activity (Jensen et al. 2014), promote general wellbeing (Appleton et al. 2018), and cope with their 
disease and its treatment in everyday life (Stuhlfauth et al. 2018). High-quality cancer care should thus incorporate such measures until completion of treatment (Kreitler 2019).

Several studies have shown that colorectal cancer patients have a requirement for nurse counseling regarding the management of symptoms and side effects (Tung et al. 2016; Shun et al. 2014; Jorgensen et al. 2012). In addition, there is currently a lack of counseling on activities of everyday living as well as on psychological and psychosocial needs, and there are problems in communication between healthcare professionals and cancer patients (Steven et al. 2019; Sakamoto et al. 2017; Harrison et al. 2009). Furthermore, a significant proportion of under-/malnourished cancer patients still do not receive adequate nutritional support (Caccialanza et al. 2017; Hébuterne et al. 2014). In Germany, deficits or even discontinuations in care can arise during the transition from the inpatient to the outpatient setting, due to different financing systems (Schlüchtermann 2020). Due to the rising incidence of cancer, outpatient support is becoming particularly important - an aspect that is barely researched and a need which is currently not well met in Germany (Stiel et al. 2009). Therefore, appropriate interventions offered by nursing and medical staff are needed to reduce these deficits in patient care. Based on the considerations outlined above, a complex intervention was developed with the aim of satisfying these unmet demands in patient care. The objective of the current health services research study was to evaluate the concept of optimized nursing and nutritional care of colorectal cancer patients in in- and outpatient settings.

The following research question was addressed: "What differences are present among a collective of colorectal cancer patients divided into a control group and an intervention group with two subgroups, one of which used inpatient and outpatient support services for oncology nurse and nutritional counseling, and the other of which used inpatient counseling services only?".

The hypothesis was that the implemented intervention with in- and optional outpatient oncology nurse counseling and systematic nutritional counseling improves discharge and side effects management as well as nutritional behavior in colorectal cancer patients.

\section{Materials and methods}

\section{Design and objective}

The current explorative, quantitative, single-center, interventional pilot study with a quasi-experimental design aimed to evaluate differences in discharge and side effects management as well as nutritional behavior between (1) colorectal cancer patients who received inpatient and optional outpatient oncology nurse counseling as well as systematic and optional outpatient nutritional counseling (intervention group) and (2) colorectal cancer patients who received routine care with no nurse counseling and only unsystematic nutritional counseling (control group). The intervention group was further divided into two subgroups: one subgroup comprising patients who received inpatient oncology nurse and systematic nutritional counseling only and another subgroup comprising patients who used the offer of in- and outpatient oncology nurse and systematic nutritional counseling.

\section{Participants and setting}

The study was performed in two general surgery wards of a colorectal cancer center in the Caritas Sankt Josef Hospital in Regensburg, Bavaria, Germany. Patients were treated according to the German S3 guideline "Colorectal Cancer" (Leitlinienprogramm Onkologie AWMF 2014). Exclusion criteria were age $<18$ years, dementia, palliative intent, and language and communication problems (Zaner 2015). Participants comprised all primary colorectal cancer patients consenting to participate, assigned to the following groups depending on treatment date: January 2014-April 2015: control group; May 2015-August 2016: intervention group. The control group was surveyed first. Thereafter, a complex intervention comprising structured in- and outpatient oncology nurse and nutritional counseling was implemented. Subsequently, the intervention group was surveyed.

\section{Complex intervention}

The structured counseling concept and complex intervention developed by the authors encompassed two components addressing treatment side effects (oncology nurse counseling) and nutrition (systematic nutritional counseling) and were tailored to different patient profiles. Until completion of treatment, colorectal cancer patients were offered easily accessible in- and outpatient counseling. The specific components of the intervention are described according to the TIDieR checklist (Hoffmann et al. 2014).

\section{Oncology nurse counseling to promote patient self-management}

The intervention was based on the two concepts of health promotion from Antonovsky's salutogenesis (1997) and Collins and Rochfort's empowerment (2016), with the promotion of patients' own skills and abilities for autonomous decision-making and independent action. By means of targeted knowledge transfer and practical guidance, patients should be able to better deal with symptoms and general treatment side effects to avoid care deficits. 
During inpatient treatment, oncology nurses advised colorectal cancer patients in the intervention group regarding preparation for discharge. Patients received information and instructions on behavior after surgery, physical activity, defecation, and, if necessary, on adjuvant treatment. Furthermore, they received a booklet with specific recommendations for side effect management during adjuvant chemotherapy. Four weeks after discharge, oncology nurses contacted patients at home via telephone. If patients required to support or advice, they received an appointment for outpatient counseling. An additional risk assessment was not performed. Appointments took place on an individual basis, either face-to-face in the hospital or, if preferred by the patient, via telephone. During these sessions, the status of symptoms and side effects was ascertained (Dodd et al. 2001). According to their needs, patients received advice/self-management instructions on mucositis (Dodd and Miaskowski 2000), hand-foot syndrome (Hartinger et al. 2012), fatigue, and sleep disorders (Aapro et al. 2017; Adlard et al. 2016; Van Vulpen et al. 2016), pain (Drury et al. 2017), and coping with everyday life (Stuhlfauth et al. 2018). Furthermore, patients' anxieties and worries were discussed (Appleton et al. 2018; Middleton 2014), and a psycho-oncologist consulted if required (Kreitler 2019). Patients were also instructed in behavioral strategies (Kwekkeboom et al. 2018) and progressive muscle relaxation techniques (Kim et al. 2016) to relax as well as aromatherapy to reduce nausea and vomiting (Zorba and Ozdemir 2018).

Oncology nurse counseling was conducted by two experienced nurses with training in oncologic care and psychooncology. Thus, patients had a constant contact person during in- and outpatient care. In preparation for the study, nurses received a one-day training in the oncology nurse counseling intervention from a research group member (MR). During the first 3 months after the implementation of oncology nurse counseling, there were weekly meetings between the nurses and MR to maintain the intervention. There were no changes in the intervention during the study. Counseling was offered in the form of individual counseling.

Patients required an average of 2.830 -min appointments within the first 6 months after discharge from the hospital until completion of adjuvant chemotherapy. There was no upper limit to the number of consultations.

\section{Systematic nutritional counseling to promote patient self-management}

With systematic in- and outpatient nutritional counseling, patients should be able to reduce gastrointestinal symptoms and side effects of treatment independently and be able to stabilize their weight due to sufficient intake of energy and protein. All patients received a brochure compiled by a clinical dietician with information on nutrition and management of gastrointestinal symptoms and treatment side effects.

Additionally, patients of the intervention group received their first systematic nutritional counseling session from a clinical dietician according to the S3 guideline "Clinical Nutrition in Oncology" (Leitlinienprogramm Onkologie 2015) during their stay in hospital. In cases of metabolic risk or under-/malnutrition (body mass index, BMI: $\leq 18.5 \mathrm{~kg} /$ $\mathrm{m}^{2}$ ) according to Nutritional Risk Screening (NRS 2002; Kondrup et al. 2003), patients were transferred to outpatient nutritional counseling. In addition, outpatient counseling services were recommended to patients who needed adjuvant chemotherapy.

During systematic outpatient nutritional counseling, side effects (abdominal pain, nausea, and vomiting, diarrhea, constipation, flatulence, loss of appetite) and weight were assessed.

The systematic counseling took place at the hospital on an individual basis with a clinical dietician according to the 2015 German S3 guideline "Clinical Nutrition in Oncology." Due to the large catchment area of the hospital, consultations were occasionally carried out by telephone. The following areas were addressed: the selection of suitable foods and drinks with concrete portion sizes; methods of food preparation; distribution of total quantities over smaller more frequent meals; enrichment of meals with sources of energy and protein; and oral nutritional supplementation (Lin et al. 2017). Between counseling sessions, patients kept a food and bowel diary, which was used to adapt the specific nutritional recommendations after each session depending on side effects and body weight (Arends et al. 2017).

Two clinical dieticians with at least 3 years of training in nutritional counseling and several years' experience in oncology conducted the in- and outpatient nutritional counseling. After the implementation of the nutritional counseling intervention, there were repeated meetings between the clinical dieticians and MR. Again, counseling was offered on an individual basis. There were no changes in the intervention during the study.

Patients required an average of 2.630 -min outpatient nutritional counseling sessions within 6 months of completing adjuvant chemotherapy. There was no upper limit to the number of consultations.

\section{Instruments and data collection}

Since validated instruments to evaluate the multimodal intervention were unavailable, a self-designed questionnaire was used. Apart from two open questions, standardized questions with closed-ended answers on a four-step rating scale were used (Gideon 2012): 5 items on sociodemographic characteristics, 19 on discharge management, 17 on treatment side 
effects, 13 on support offers, and 13 questions on nutrition during treatment; 2 further questions on the use of in- and outpatient oncology nurse and nutritional counseling were provided only to intervention group patients. The questionnaire was evaluated with a classical pretest. With Cronbach's alpha for four sets of questions each comprising 5-13 individual questions ranging from 0.66 to 0.80 , the internal consistency of the questionnaire was acceptable (De Smith 2018).

Data were collected about 6 months after surgery. Due to the timeframe of 16 months defined by the hospital for enrollment of each group, we expected to include approximately 150 patients in the control and 150 patients in the intervention group.

The course of outpatient counseling in the intervention group was documented in the hospital information system (HIS) by the oncology nurses and clinical dieticians and data were analyzed.

\section{Statistical analysis}

Data were analyzed using SPSS version 25 (IBM Corp., Armonk, NY, USA). Descriptive statistics employed univariate methods and relative frequencies are reported in tables and figures. Pearson's nonparametric $\chi^{2}$ test was used to test the independence of paired categorical variables (De Smith 2018). Significance was set at $p<0.05$.
Subgroup analyses were performed by subdividing the intervention group into patients who received only inpatient counseling and patients who received both in- and outpatient counseling. Subgroups were compared with control group patients. Correction for multiple testings was not applied.

\section{Results}

A total of 141 questionnaires were sent to control group patients, of which 75 were returned (return rate of 53.2\%). A total of 153 questionnaires were sent to intervention group patients, of which 114 were returned (return rate of 74.5\%).

Sociodemographic and treatment characteristics of the total sample of 189 patients as well as of the control and intervention arms are shown in Table 1. Only in terms of gender distribution was there a significant difference between the control and intervention groups $(p=0.022)$.

\section{Oncology nurse counseling}

\section{Discharge management}

Table 2 shows better results for the intervention group compared to the control group in the following aspects of discharge management: more frequent notice of discharge date 2 days in advance $(77.2 \% ; p=0.045)$, more frequent discharge consultation with a physician $(85.1 \%$;
Table 1 Comparison of sociodemographic and treatment variables in control and total intervention group

\begin{tabular}{|c|c|c|c|c|c|c|c|}
\hline & \multicolumn{2}{|c|}{$\begin{array}{l}\text { Control group } \\
(n=75)\end{array}$} & \multicolumn{2}{|c|}{$\begin{array}{l}\text { Total interven- } \\
\text { tion group } \\
(n=114)\end{array}$} & \multicolumn{2}{|c|}{ Total $(n=189)$} & \multirow[t]{2}{*}{$p$-value } \\
\hline & $n$ & $\%$ & $n$ & $\%$ & $n$ & $\%$ & \\
\hline \multicolumn{8}{|l|}{ Gender } \\
\hline Female & 23 & 30.7 & 54 & 47.4 & 77 & 40.7 & 0.022 \\
\hline Male & 52 & 69.3 & 60 & 52.6 & 112 & 59.3 & \\
\hline \multicolumn{8}{|l|}{ Age (years) } \\
\hline$<50$ & 7 & 9.3 & 8 & 7.0 & 15 & 7.9 & 0.545 \\
\hline $50-59$ & 16 & 21.3 & 24 & 21.1 & 40 & 21.2 & \\
\hline $60-69$ & 18 & 24.0 & 38 & 33.3 & 56 & 29.6 & \\
\hline$\geq 70$ & 34 & 45.3 & 44 & 38.6 & 78 & 41.3 & \\
\hline \multicolumn{8}{|l|}{ Marital status/living arrangement } \\
\hline Married/living with partner & 61 & 81.3 & 86 & 75.4 & 147 & 77.8 & 0.472 \\
\hline Living with children/other relatives & 2 & 2.7 & 7 & 6.1 & 9 & 4.8 & \\
\hline Living alone & 12 & 16.0 & 21 & 18.4 & 33 & 17.5 & \\
\hline \multicolumn{8}{|l|}{ Treatment } \\
\hline Op & 74 & 98.7 & 112 & 98.2 & 186 & 98.4 & 0.821 \\
\hline $\mathrm{Rad} /$ chemo & 26 & 34.7 & 34 & 29.8 & 60 & 31.7 & 0.484 \\
\hline Chemo & 35 & 46.7 & 57 & 50.0 & 92 & 48.7 & 0.654 \\
\hline
\end{tabular}

$P$ values refer to $\mathrm{X}^{2}$ tests

$O p$ surgery, rad/chemo radiochemotherapy, chemo chemotherapy 
Table 2 Hospital discharge procedure in the control and intervention groups

\begin{tabular}{|c|c|c|c|c|c|}
\hline & \multicolumn{2}{|c|}{$\begin{array}{l}\text { Control group: no } \\
\text { nurse counseling } \\
(n=75)\end{array}$} & \multicolumn{2}{|c|}{$\begin{array}{l}\text { Total intervention } \\
\text { group: inpatient and } \\
\text { optional outpatient } \\
\text { nurse counseling } \\
(n=114)\end{array}$} & \multirow[t]{2}{*}{$p$-value } \\
\hline & $n$ & $\%$ & $n$ & $\%$ & \\
\hline Notice of discharge date 2 days in advance & 51 & 68.0 & 88 & 77.2 & 0.045 \\
\hline Discharge consultation with a physician & 54 & 72.0 & 97 & 85.1 & 0.017 \\
\hline Discussion of worries and troubles & 22 & 29.3 & 54 & 47.4 & 0.004 \\
\hline Inclusion of relatives in the course of treatment & 32 & 42.7 & 59 & 51.8 & 0.018 \\
\hline Information on social law issues & 29 & 38.7 & 70 & 61.4 & 0.015 \\
\hline Transfer to outpatient nutritional counseling & 18 & 24.0 & 62 & 54.4 & $<0.001$ \\
\hline Receipt of brochures on colorectal cancer & 45 & 60.0 & 98 & 86.0 & $<0.001$ \\
\hline
\end{tabular}

$P$ values refer to $\mathrm{X}^{2}$ tests
Table 3 General treatment side effects in the control and intervention groups

\begin{tabular}{|c|c|c|c|c|c|}
\hline & \multicolumn{2}{|c|}{$\begin{array}{l}\text { Control group: } \\
\text { no nurse coun- } \\
\text { seling }(n=75)\end{array}$} & \multicolumn{2}{|c|}{$\begin{array}{l}\text { Total interven- } \\
\text { tion group: } \\
\text { inpatient and } \\
\text { optional out- } \\
\text { patient nurse } \\
\text { counseling } \\
(n=114)\end{array}$} & \multirow[t]{2}{*}{$p$-value } \\
\hline & $n$ & $\%$ & $n$ & $\%$ & \\
\hline General side effects & 48 & 64.0 & 78 & 69.3 & 0.448 \\
\hline Fever/allergy & 6 & 8.0 & 5 & 4.4 & 0.299 \\
\hline Oral mucositis & 7 & 9.3 & 22 & 19.3 & 0.063 \\
\hline Dizziness & 14 & 18.7 & 33 & 28.9 & 0.110 \\
\hline Hand-foot syndrome & 20 & 26.7 & 41 & 36.0 & 0.181 \\
\hline Breathing difficulties & 8 & 10.7 & 12 & 10.5 & 0.976 \\
\hline Fatigue syndrome & 36 & 48.0 & 56 & 49.1 & 0.880 \\
\hline Sleep disorders & 21 & 28.0 & 26 & 22.8 & 0.419 \\
\hline Anxiety/depression & 14 & 18.7 & 23 & 20.2 & 0.798 \\
\hline
\end{tabular}

$P$ values refer to $\mathrm{X}^{2}$ tests

$p=0.017$ ), more opportunities for the discussion of worries and troubles $(47.4 \% ; p=0.004)$, better inclusion of relatives in the course of treatment $(51.8 ; p=0.018)$, more information on social law issues $(61.4 \% ; p=0.015)$, more frequent transfer to outpatient nutritional counseling $(54.4 \% ; p<0.001)$, and colorectal cancer brochures more frequently distributed to patients $(86.0 \% ; p<0.001)$

\section{General treatment side effects}

The data presented in Table 3 on general treatment side effects relate to the time period between discharge from hospital until 1 month after completion of adjuvant chemotherapy. There were no significant differences between the control and the intervention group in terms of self-reported general treatment side effects.

\section{Subgroup analysis for general treatment side effects}

Even when compared between three study groups, there are no significant differences in the general side effects of treatment (Table 4).

\section{Patient-reported outcomes}

Of the 74 patients in the intervention group with in- and outpatient oncology nurse counseling, 66 (89.2\%) reported being more able to cope with adverse effects of adjuvant chemotherapy (Fig. 1a). Furthermore, 73 (98.7\%) patients were better able to assess their own requirements and concerns (Fig. 1b) and all 74 (100.0\%) reported having had a trusted contact person until 1 month after the completion of adjuvant chemotherapy (Fig. 1c).

\section{Counselor-reported outcomes (data from the HIS)}

In Table 5, six relevant general side effects affecting the 74 patients participating in both in- and outpatient oncology nurse counseling are presented. Moreover, the specific interventions applied to combat these side effects and the outcomes thereof up until 1 month after completion of adjuvant chemotherapy are described.

\section{Nutritional counseling}

\section{Gastrointestinal side effects}

The data on gastrointestinal (GI) treatment side effects relate to the time period between discharge from hospital until 1 month after completion of adjuvant chemotherapy. 
Table 4 Subgroup analysis of general treatment side effects in the three study groups with different oncology nurse counseling

\begin{tabular}{|c|c|c|c|c|c|c|c|}
\hline & \multicolumn{2}{|c|}{$\begin{array}{l}\text { Control group: no } \\
\text { nurse counseling } \\
(n=75)\end{array}$} & \multicolumn{2}{|c|}{$\begin{array}{l}\text { Intervention group: } \\
\text { inpatient nurse coun- } \\
\text { seling only }(n=40)\end{array}$} & \multicolumn{2}{|c|}{$\begin{array}{l}\text { Intervention group: } \\
\text { in- and outpatient } \\
\text { nurse counseling } \\
(n=74)\end{array}$} & \multirow[t]{2}{*}{$p$-value } \\
\hline & $n$ & $\%$ & $n$ & $\%$ & $n$ & $\%$ & \\
\hline General side effects & 48 & 64.0 & 26 & 65.0 & 52 & 70.3 & 0.697 \\
\hline Fever/allergy & 6 & 8.0 & 1 & 2.5 & 4 & 5.4 & 0.478 \\
\hline Oral mucositis & 7 & 9.3 & 8 & 20.0 & 14 & 18.9 & 0.175 \\
\hline Dizziness & 14 & 18.7 & 8 & 20.0 & 25 & 33.8 & 0.074 \\
\hline Hand-foot syndrome & 20 & 26.7 & 13 & 32.5 & 28 & 37.8 & 0.345 \\
\hline Breathing difficulties & 8 & 10.7 & 5 & 12.5 & 7 & 9.5 & 0.880 \\
\hline Fatigue syndrome & 36 & 48.0 & 22 & 55.0 & 34 & 45.9 & 0.646 \\
\hline Sleep disorders & 21 & 28.0 & 9 & 22.5 & 17 & 23.0 & 0.720 \\
\hline Anxiety/depression & 14 & 18.7 & 6 & 15.0 & 17 & 23.0 & 0.564 \\
\hline
\end{tabular}

$P$ values refer to $\mathrm{X}^{2}$ tests
In the data comparison between the control and intervention groups (Table 6), intervention group patients reported the two GI side effects xerostomia $(40.4 \% ; p=0.20)$ and dysphagia $(15.8 \% ; p=0.012)$ significantly more often.

\section{Subgroup analysis for gastrointestinal side effects}

Of the 114 patients in the total intervention group, 62 (54.4\%) received inpatient systematic nutritional counseling only and $52(45.6 \%)$ participated in- and outpatient counseling.

Patients of the intervention group with in- and outpatient systematic nutritional counseling had significantly more food intolerances $(40.4 \%)$ than patients in the intervention group with inpatient nutritional counseling only (22.6\%) or control patients $(20.0 \%$; $p=0.026)$. Furthermore, patients of the intervention group with inpatient systematic nutritional counseling reported significantly more chewing difficulties and dysphagia $(17.7 \% ; p=0.032$; Table 7$)$.

\section{Patient-reported outcomes}

Table 8 shows significant differences concerning nutritional advice between the control and intervention groups. Intervention group patients significantly more often reported that they had received extensive information via nutritional counseling $(73.6 \% ; p=0.043)$ and adequate information on nutrition in colorectal cancer $(86.0 \% ; p<0.001)$. Furthermore, they felt able to gauge intolerances or complaints more frequently $(68.4 \% ; p=0.012)$ and followed the recommendations of the nutrition counselor more often $(73.7 \%$; $p=0.001)$.

\section{Subgroup analysis for patient-reported outcomes}

According to the reports of patients of both intervention groups, they received information and concrete instructions regarding the return to solid food and nutrition significantly more often during their stay in hospital ( $p=0.013$; Fig. 2a). Additionally, they more often received satisfactory information on colorectal cancer $(p<0.001$; Fig. $2 b)$. Moreover, patients of the intervention groups more often reported being better able to gauge food intolerances and GI side effects after in- and outpatient nutritional counseling $(p=0.023$; Fig. 2c), and followed the counselor`s advice ( $p=0.003$; Fig. 2d).

\section{Counselor-reported outcomes (data from the HIS)}

In Table 9, six relevant GI side effects affecting the 52 patients participating in both in- and outpatient systematic nutritional counseling are presented. Moreover, the specific interventions applied to combat these GI side effects and the outcomes thereof up until 1 month after completion of adjuvant chemotherapy are described.

\section{Discussion}

Structured outpatient oncology nurse and nutritional interventions for colorectal cancer patients are rare in Germany. The presented study demonstrates that the development of a structured in- and outpatient counseling concept has some positive effects on discharge and side effects management as well as on patients' nutritional behavior. The concept helps to reduce the gap in cancer care. This can only be achieved 
a

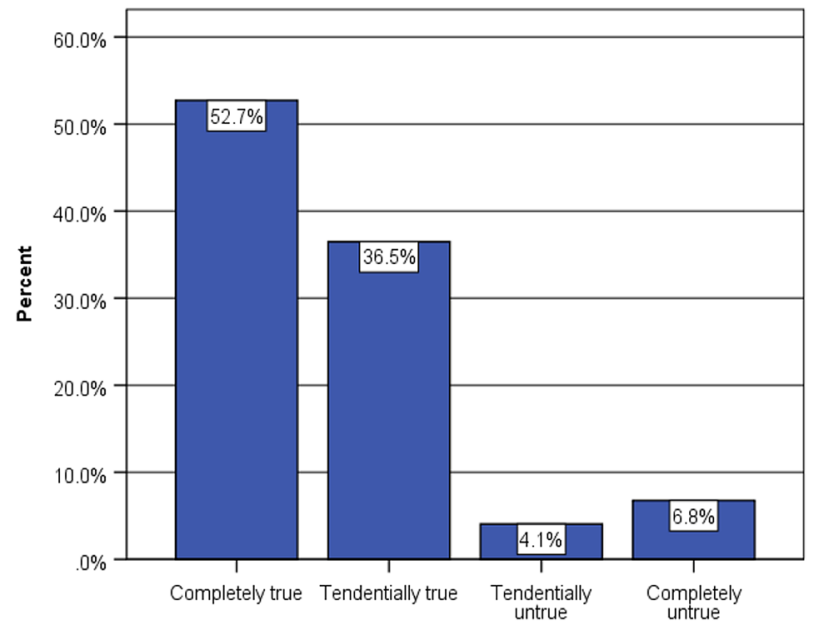

b

Improved coping with treatment side effects
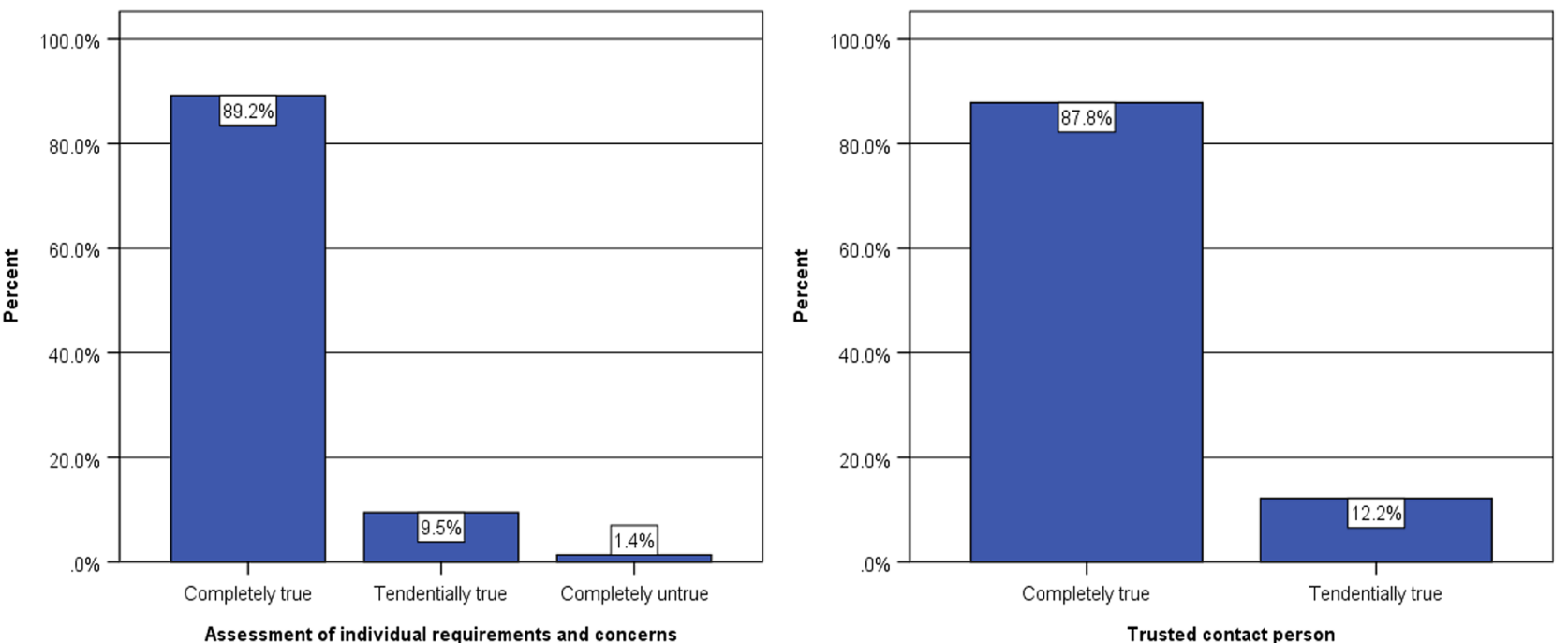

Fig. 1 Results of oncology nurse counseling in the intervention group with in- and outpatient counseling $(n=74)$

Table 5 Relevant general treatment side effects in patients of the intervention group with in- and outpatient nurse counseling $(n=74)$

\begin{tabular}{llll}
\hline General treatment side effects & $n(\%)$ & Nursing interventions & $\begin{array}{l}\text { Outcomes until 1 month after the } \\
\text { end of treatment }\end{array}$ \\
\hline Fatigue & $34(45.9)$ & $\begin{array}{l}\text { Progressive muscle relaxation } \\
\text { Endurance training targets } \\
\text { Behavioral strategies } \\
\text { Progressive muscle relaxation } \\
\text { Cold water bath }\end{array}$ & $\begin{array}{l}\text { Improvement in 28 (82.4\%) patients } \\
\text { Oil blends and cremes } \\
\text { Hand-foot syndrome }\end{array}$ \\
Anxiety/depression & $17(23.0)$ & $\begin{array}{l}\text { Improvement in 11 (64.7\%) patients } \\
\text { Consultation with nurse }\end{array}$ & Improvement in 21 (75.0\%) patients \\
Oral mucositis & $17(23.0)$ & $\begin{array}{l}\text { Self-care instructions for antiseptic/analge- } \\
\text { sic substances } \\
\text { Coordination and balance exercises }\end{array}$ & Improvement in 14 (100.0\%) patients \\
Dizziness and balance disorders & $14(18.9)$ & Improvement in 15 (60.0\%) patients \\
\hline
\end{tabular}


Table 6 Gastrointestinal side effects in the control and intervention groups

\begin{tabular}{|c|c|c|c|c|c|}
\hline & \multicolumn{2}{|c|}{$\begin{array}{l}\text { Control group: } \\
\text { unsystematic } \\
\text { nutritional coun- } \\
\text { seling }(n=75)\end{array}$} & \multicolumn{2}{|c|}{$\begin{array}{l}\text { Total interven- } \\
\text { tion group: } \\
\text { systematic } \\
\text { inpatient and } \\
\text { optional outpa- } \\
\text { tient nutritional } \\
\text { counseling } \\
(n=114)\end{array}$} & \multirow[t]{2}{*}{$p$-value } \\
\hline & $n$ & $\%$ & $n$ & $\%$ & \\
\hline GI side effects & 44 & 58.7 & 72 & 63.2 & 0.789 \\
\hline Weight loss & 26 & 34.7 & 49 & 43.0 & 0.253 \\
\hline Abdominal pain & 15 & 20.0 & 17 & 14.9 & 0.362 \\
\hline Food intolerances & 15 & 20.0 & 35 & 30.7 & 0.103 \\
\hline Nausea/vomiting & 17 & 22.7 & 27 & 23.7 & 0.871 \\
\hline Diarrhea & 27 & 36.0 & 53 & 46.5 & 0.153 \\
\hline Loss of appetite & 19 & 25.3 & 37 & 32.5 & 0.294 \\
\hline Xerostomia & 18 & 24.0 & 46 & 40.4 & 0.020 \\
\hline Dysphagia & 3 & 4.0 & 18 & 15.8 & 0.012 \\
\hline
\end{tabular}

$P$ values refer to $\mathrm{X}^{2}$ tests

by interdisciplinary cooperation between treating physicians, oncology nurses, and clinical dietitians.

The age distribution in the current study corresponded to that of a normal colorectal cancer collective in Germany according to the Robert-Koch-Institut (2017). The study groups were imbalanced in terms of gender, an effect which likely resulted from the small size of the study groups. Men develop rectal carcinoma significantly more often, which may explain the gender distribution (Robert-Koch-Institut 2017; Marks 2017).
Furthermore, most patients in the current study lived in a familial environment. Previous studies have shown social support and family solidarity to reduce patients' psychoemotional stress, promote their wellbeing, and positively influence coping with the disease and its treatment (Stuhlfauth et al. 2018; Corner et al. 2013; Usta 2012).

In contrast to the control group, patients of the intervention group profited significantly from inpatient oncology nurse counseling in seven areas of discharge management. Similar to the findings of Stuhlfauth et al. (2018) and Waring et al. (2014), these patients received more behavioral information and instructions, which eased the transition from hospital to their home environment and gave them more security in everyday life. Effective coordination of this key process and intensive provision of information by physicians and oncology nurses also reduced stress and anxiety in patients and relatives in the study by Carroll and Dowling (2013). In their review, Nosbusch et al. (2011) found that nurses are highly qualified to identify barriers and challenges in discharge management. Furthermore, effective discharge planning can help patients to better manage symptoms and side effects at home.

Of the 74 intervention group patients with in- and outpatient oncology nurse counseling, most were better able to cope with adverse effects of adjuvant chemotherapy. It is assumed that analogous to the effects observed by Aapro et al. (2017), Adlard et al. (2016), Van Vulpen et al. (2016), and Jensen et al. (2014), the training in progressive muscle relaxation and moderate endurance training led to improvements in most patients with fatigue and sleep disorders. In their systematic review of patients with colorectal cancer, Bradenbarg et al. (2017) were unable to demonstrate significant improvements in this regard.
Table 7 Subgroup analysis of gastrointestinal side effects in the three study groups with different nutritional counseling

\begin{tabular}{|c|c|c|c|c|c|c|c|}
\hline & \multicolumn{2}{|c|}{$\begin{array}{l}\text { Control group: unsys- } \\
\text { tematic nutritional } \\
\text { counseling }(n=75)\end{array}$} & \multicolumn{2}{|c|}{$\begin{array}{l}\text { Intervention group: } \\
\text { inpatient systematic } \\
\text { nutritional counseling } \\
\text { only }(n=62)\end{array}$} & \multicolumn{2}{|c|}{$\begin{array}{l}\text { Intervention group: } \\
\text { in- and outpatient } \\
\text { systematic nutritional } \\
\text { counseling }(n=52)\end{array}$} & \multirow[t]{2}{*}{$p$-value } \\
\hline & $n$ & $\%$ & $n$ & $\%$ & $n$ & $\%$ & \\
\hline GI side effects & 44 & 58.7 & 39 & 62.9 & 33 & 63.5 & 0.823 \\
\hline Weight loss & 26 & 34.7 & 25 & 40.3 & 24 & 46.2 & 0.426 \\
\hline Abdominal pain & 15 & 20.0 & 9 & 14.5 & 8 & 15.4 & 0.655 \\
\hline Food intolerances & 15 & 20.0 & 14 & 22.6 & 21 & 40.4 & 0.026 \\
\hline Nausea/vomiting & 17 & 22.7 & 13 & 21.0 & 14 & 26.9 & 0.745 \\
\hline Diarrhea & 27 & 36.0 & 27 & 43.5 & 26 & 50.0 & 0.283 \\
\hline Loss of appetite & 19 & 25.3 & 17 & 27.4 & 20 & 38.5 & 0.252 \\
\hline Xerostomia & 18 & 24.0 & 25 & 40.3 & 21 & 40.4 & 0.067 \\
\hline Dysphagia & 3 & 4.0 & 11 & 17.7 & 7 & 13.5 & 0.032 \\
\hline
\end{tabular}

GI gastrointestinal

$P$ values refer to $\mathrm{X}^{2}$ tests 
Table 8 Results of nutritional counseling in the control and intervention groups

\begin{tabular}{|c|c|c|c|c|c|}
\hline & \multicolumn{2}{|c|}{$\begin{array}{l}\text { Control } \\
\text { group: } \\
\text { unsystematic } \\
\text { nutritional } \\
\text { counseling } \\
(n=75)\end{array}$} & \multicolumn{2}{|c|}{$\begin{array}{l}\text { Total } \\
\text { interven- } \\
\text { tion group: } \\
\text { systematic } \\
\text { nutritional } \\
\text { counseling } \\
\text { and optional } \\
\text { outpatient } \\
\text { nutritional } \\
\text { counseling } \\
(n=114)\end{array}$} & \multirow[t]{2}{*}{$p$-value } \\
\hline & $n$ & $\%$ & $n$ & $\%$ & \\
\hline Extensive information received via nutritional counseling & 40 & 53.3 & 84 & 73.6 & 0.043 \\
\hline Adequate information on nutrition in colorectal cancer patients & 40 & 53.3 & 98 & 86.0 & $<0.001$ \\
\hline Better gauging of intolerances/complaints & 35 & 46.7 & 78 & 68.4 & 0.012 \\
\hline $\begin{array}{l}\text { Followed recommendations of the nutritional counselor in case } \\
\text { of adverse events }\end{array}$ & 36 & 48.0 & 84 & 73.7 & 0.001 \\
\hline
\end{tabular}

$p$-values refer to $\mathrm{X}^{2}$ tests
After repeated outpatient practical instruction in the use of the PRO-SELF Program from Dodd \& Miaskowski (2000), mucositis improved in all affected patients. Due to the study design, it is not possible to infer a direct effect of the PRO-SELF Program on mucositis. Self-management programs contribute significantly to reducing the burden of symptoms and side effects (Howell et al. 2017). However, some systematic reviews indicate that these programs are limited by a lack of practical instructions and appreciation of cultural differences (Hammer et al. 2015; Gao and Yuan 2011).

As in the studies by Appleton et al. (2018), and Middleton (2014), in- and outpatient oncology nurse counseling in the present intervention also focused on the psychological and emotional status of the patients. Specialized oncology nurses play a key role at the interface between medicine and psychology because they often have more personal and continuous contact with the patients compared to other healthcare professionals, and patients are thus frequently more open toward them. Therefore, nurses can detect changes in patients' psychological well-being early (Mehnert and Lordick 2017). The American Society of Clinical Oncology also recommends the support of qualified oncology nurses to reduce psychosocial distress in cancer patients (Andersen et al. 2014). The investigations of Guo et al. (2013) and Booth et al. (2005) found that cancer patients who received psycho-oncological care from specialized oncology nurses showed a reduction in anxiety and depressed mood. In the present study, a psycho-oncologist was consulted in cases of high-stress levels. In a systematic review of 14 randomized controlled trials (RCT) on psychosocial interventions in patients with colorectal cancer, only three studies showed a significant effect on the reduction of anxiety and depression (Mosher et al. 2017). Since there is currently a lack of standardized interventions in psycho-oncological patient care, systematic reviews and meta-analyses show a high degree of study heterogeneity (Jenniches et al. 2020).

Up until now, only a few studies have investigated the effects of posthospitalization nursing interventions on the outcome of colorectal cancer patients (Zhanga et al. 2014; Anderson et al. 2013; Gray et al. 2013; Grant et al. 2011), although several studies have indicated unmet counseling requirements in this patient group (Sakamoto et al. 2017; Tung et al. 2016; Shun et al. 2014; Jorgensen et al. 2012).

Although many national and international recommendations on nutrition in cancer patients have been published (Arends et al. 2017; August et al. 2009), a large proportion of under-/malnourished patients do not receive adequate dietary support (Caccialanza et al. 2017; Hébuterne et al. 2014). This demonstrates that systematic nutritional interventions are not yet fully established in oncologic practice, although under-/malnourishment during cancer treatment is a negative prognostic factor (Ravasco 2019).

Of the 52 intervention group patients who participated in outpatient nutritional counseling during adjuvant chemotherapy, $38 \%$ were able to gain or stabilize their weight through a special protein-rich high-calory diet. The RCT from Ravasco et al. (2012) also showed that intensive nutritional counseling of colorectal cancer patients is the most effective means of improving nutritional status during radiotherapy. Lin et al. (2017) and Dobrila-Dintinjana et al. (2013) also demonstrated that individual nutritional counseling and administration of dietary supplements reduced weight loss and improved appetite in colorectal cancer patients, thus stabilizing nutritional status and reducing chemotherapyinduced morbidity. 
a

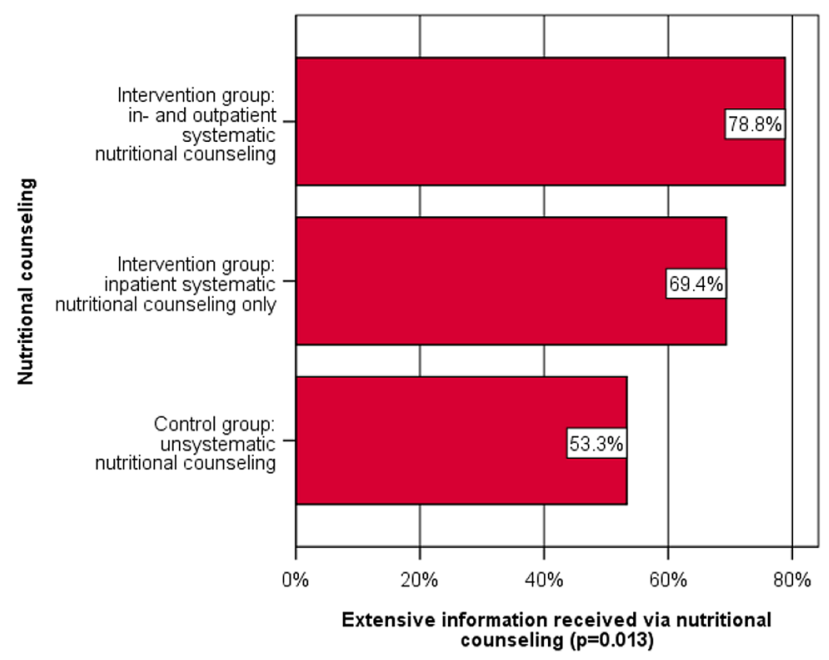

C

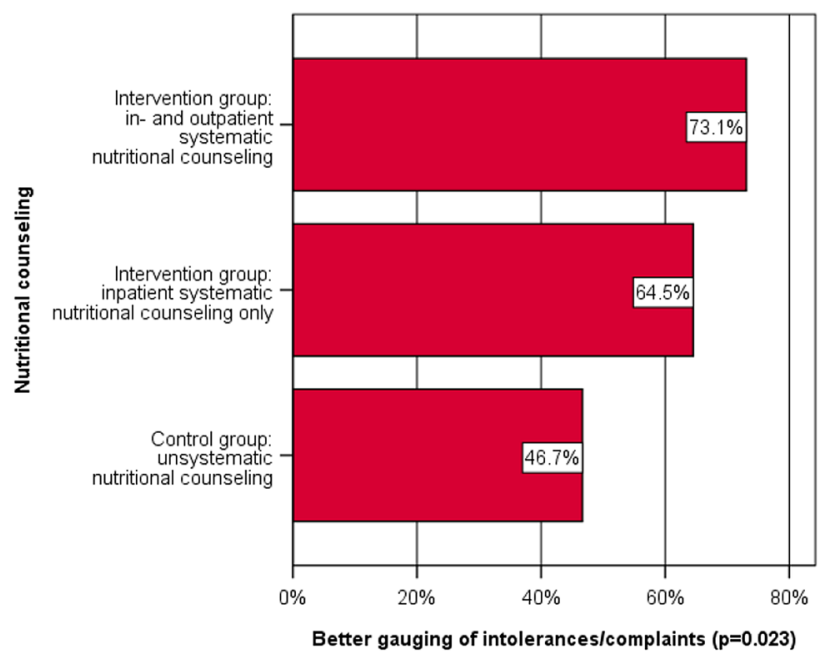

b

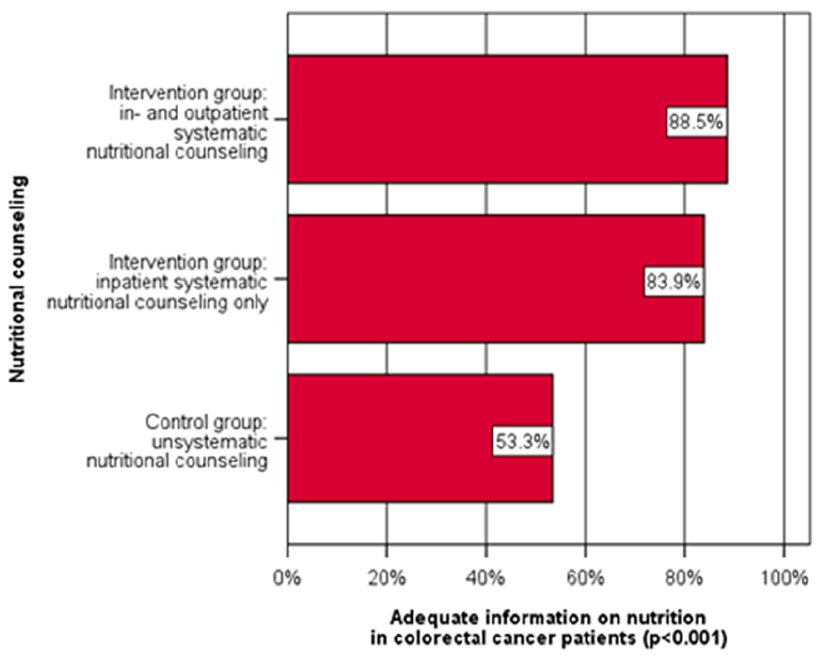

d

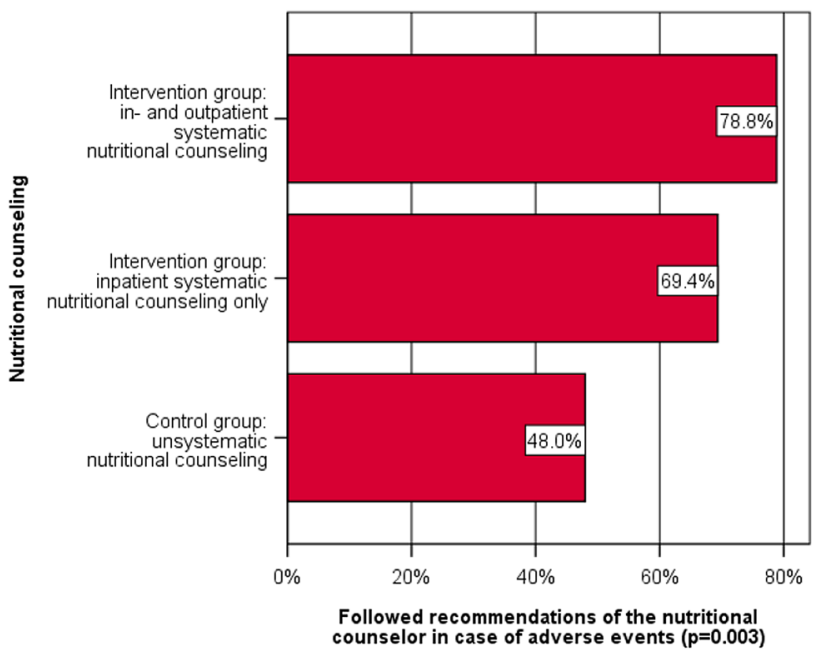

Fig. 2 Subgroup analysis of results of in- and outpatient nutritional counseling in the three study groups, $p$-values refer to $X^{2}$ tests

In the current study, the intensity of nutritional counseling depended on the frequency of GI side effects, which were most frequent in the intervention group with the use of inand outpatient counseling. Nutritional and behavioral recommendations in outpatient counseling are assumed to have led to the improvement of diarrhea in almost all patients, reduction of nausea in all patients, and increased appetite in half of the patients. Nutritional behavior is the only factor that patients can control for addressing intolerance and other GI side effects during treatment (Ravasco 2019). According to Cotogni et al. (2019), nutritional counseling in tumor patients helps not only to improve body weight but also to reduce the incidence and severity of toxicity during adjuvant chemotherapy or radiotherapy, so that interruptions to treatment can be avoided.

An effective self-management program-supported by clinical dieticians and nurses_-promoting patients' wellbeing and everyday functioning is thus of central importance (Hammer et al. 2015). In their systematic review of patients with GI and lung cancers, Baldwin et al. (2012) were unable to show the positive effects of oral nutritional interventions. Within a heterogeneous landscape of studies, there are only a few RCTs with well-described and comparable nutritional interventions for cancer patients (Cotogni et al. 2019; Solheim et al. 2019). Varying criteria for the 
Table 9 Relevant gastrointestinal side effects in the intervention group with in- and outpatient systematic nutritional counseling $(n=52)$

\begin{tabular}{|c|c|c|c|}
\hline Side effect & $n(\%)$ & Interventions & $\begin{array}{l}\text { Outcomes until } 1 \text { month after the } \\
\text { end of treatment }\end{array}$ \\
\hline Weight loss & $24(46.2)$ & $\begin{array}{l}\text { Protein-rich/high-calory diet } \\
\text { Dietary supplements }\end{array}$ & $\begin{array}{l}14(58.3 \%) \text { weight gain } \\
6(25.0 \%) \text { weight stabilization } \\
4(16.7 \%) \text { further weight loss }\end{array}$ \\
\hline Diarrhea & $26(50.0)$ & $\begin{array}{l}\text { Special diet } \\
\text { Well-tolerated foods }\end{array}$ & Improvements in $21(80.8 \%)$ patients \\
\hline Food intolerances & $21(40.4)$ & $\begin{array}{l}\text { Easily digestible foods/drinks } \\
\text { Food preparation instructions } \\
\text { Several small meals a day }\end{array}$ & Improvements in $19(90.5 \%)$ patients \\
\hline Loss of appetite & $20(38.5)$ & $\begin{array}{l}\text { Several small meals a day } \\
\text { Pepsin wine } \\
\text { Eat in company }\end{array}$ & Improvement in $11(55.0 \%)$ patients \\
\hline Xerostomia & $21(40.4)$ & $\begin{array}{l}\text { Oral rinses } \\
\text { Cold drinks } \\
\text { Boiled sweets }\end{array}$ & Improvement in $21(100.0 \%)$ patients \\
\hline Nausea/vomiting & $14(26.9)$ & $\begin{array}{l}\text { Aromatherapy } \\
\text { Antiemetics }\end{array}$ & Improvement in $14(100.0 \%)$ patients \\
\hline
\end{tabular}

assessment of nutritional status and different nutritional patterns in diverse ethnic groups lead to divergent outcomes.

\section{Limitations}

The small sample sizes of study groups are a limitation of the current work, which may have precluded recognition of relevant differences in the analysis. The power and generalizability of the results are thus limited (De Smith 2018). Bias due to social desirability cannot be excluded. The study design with quasi-experimental, non-randomized groups and lack of blinding precludes conclusions on causality. Furthermore, because of the explorative character of the study and multiple testings, the results should be interpreted in an exploratory manner.

\section{Conclusion and implications for practice}

Oncology nurse and nutritional counseling appear to help patients to develop effective self-management strategies to cope with general and GI treatment side effects and psychosocial stress in everyday life. Patients also have a trusted contact person until the end of treatment. Application of salutogenic (Antonovsky 1997) and empowerment (Collins and Rochfort 2016) concepts also renders patients more able to manage their disease and return to normal life after the end of treatment. Furthermore, inpatient oncology nurse counseling appears to significantly improve discharge management.
Further interventional studies on the care requirements of cancer patients are necessary to develop and implement structured in- and particularly outpatient support services targeting symptom and side effects management, nutritional behavior, and psychosocial counseling (Scott et al. 2017). In light of the increasing number of cancer patients, these interventions must be specific, effective, and sustainable. Outpatient counseling should be available to all cancer patients requiring it.

A positive effect of the current study is that the in- and outpatient counseling services have now been extended to all types of solid tumors at the authors' hospital.

Acknowledgements The authors thank all the colorectal cancer patients who generously agreed to participate.

All participants obtained a detailed description of the study and were enrolled in the study after providing written informed consent. The study was approved by the ethics committee of the University of Regensburg (registration number 15-101-0185) and is in accordance with the 1964 Helsinki Declaration and its later amendments.

Funding Open Access funding enabled and organized by Projekt DEAL and Tumor Center Regensburg-Institute of Quality Management and Health Services Research of the University of Regensburg.

\section{Compliance with ethical standards}

Conflict of interest Margarete Reiter, Michael Gerken, Patricia Lindberg-Scharf, Alois Fuerst, Gudrun Liebig-Hörl, Olaf Ortmann, Ingeborg Eberl, and Sabine Bartholomeyczik declare that they have no conflict of interest.

Open Access This article is licensed under a Creative Commons Attribution 4.0 International License, which permits use, sharing, adaptation, distribution and reproduction in any medium or format, as long as you give appropriate credit to the original author(s) and the source, 
provide a link to the Creative Commons licence, and indicate if changes were made. The images or other third party material in this article are included in the article's Creative Commons licence, unless indicated otherwise in a credit line to the material. If material is not included in the article's Creative Commons licence and your intended use is not permitted by statutory regulation or exceeds the permitted use, you will need to obtain permission directly from the copyright holder. To view a copy of this licence, visit http://creativecommons.org/licenses/by/4.0/.

\section{References}

Aapro M, Scotte F, Bouillet T, Currow D, Vigano A (2017) A practical approach to fatigue management in colorectal cancer. Clin Colorectal Cancer 16(4):275-285. https://doi.org/10.1016/j. clcc.2016.04.010

Adlard KN, Devin JL, Jenkins DG, Bolam KA, Aitken JF, Chambers SK, Dunn JC, Skinner TL (2016) The influence of exercise intensity on fatigue in colorectal cancer survivors: a randomized controlled trial. Asia-Pac J Clin Onco 12:78

Andersen BL, DeRubeis RJ, Berman BS, Gruman J, Champion VL, Massie MJ, Holland JC, Partridge AH, Bak K, Somerfield M, Rowland JH (2014) Screening, assessment, and care of anxiety and depressive symptoms in adults with cancer: an American Society of Clinical Oncology guideline adaptation. J Clin Oncol 32(15):1605-1619. https://doi.org/10.1200/JCO.2013.52.4611

Anderson AS, Steele R, Coyle J (2013) Lifestyle issues for colorectal cancer survivors - perceived needs, beliefs and opportunities. Support Care Cancer 21:35-42. https://doi.org/10.1007/s0052 0-012-1487-7

Antonovsky A (1997) Salutogenese. Zur Entmystifizierung der Gesundheit. (Forum für Verhaltenstherapie und psychosoziale Praxis). DGVT-Verlag, Tübingen, pp 13-53

Appleton L, Poole H, Wall C (2018) Being in safe hands: Patients' perceptions of how cancer services may support psychological well-being. J Adv Nurs 74(7):1531-1543. https://doi. org/10.1111/jan. 13553

Arends J, Bachmann P, Baracos V, Barthelemy N, Bertz H, Bozzetti F, Fearon K, Hütterer E, Isenring E, Kaasa S, Krznaric Z, Laird B, Larsson M, Laviano A, Mühlebach S, Muscaritoli M, Oldervoll L, Ravasco P, Solheim T, Strasser F, De van der Schueren M, Preiser JC (2017) ESPEN guidelines on nutrition in cancer patients. Clin Nutr 36(1):11-48. https://doi.org/10.1016/j. clnu.2016.07.015

August DA, Huhmann MB, American Society for Parenteral, Enteral Nutrition (ASPEN) Board of Directors (2009) ASPEN clinical guidelines: nutrition support therapy during adult anticancer treatment and in hematopoietic cell transplantation. JPEN J Parenter Enteral Nutr 33(5):472-500. https://doi.org/10.1177/0148607109 341804

Baldwin C, Spiro A, Ahern R, Emery RA (2012) Oral nutritional interventions in malnourished patients with cancer: a systematic review and meta analysis. J Natl Cancer Inst 104:371-385. https ://doi.org/10.1093/jnci/djr556

Booth K, Beaver K, Kitchener H, O’Neill J, Farrell C (2005) Women's experiences of information, psychological distress and worry after treatment for gynaecological cancer. Patient Educ Couns 56(2):225-232

Brandenbarg D, Korsten JH, Berger M, Berendsen AJ (2017) The effect of physical activity on fatigue among survivors of colorectal cancer: a systematic review and meta-analysis. Support Care Cancer 26(2):393-403. https://doi.org/10.1007/s00520-017-3920-4

Caccialanza R, De Lorenzo F, Gianotti L, Zagonel V, Gavazzi C, Farina G, Cotogni P, Cinieri S, Cereda E, Marchetti P, Nardi M, Iannelli
E, Santangelo C, Traclò F, Pinto C, Pedrazzoli P (2017) Nutritional support for cancer patients: still a neglected right? Support Care Cancer 25(10):3001-3004. https://doi.org/10.1007/s0052 0-017-3826-1

Carroll A, Dowling M (2013) Discharge planning: communication, education and patient participation. Br J Nurs 16(14):882-886. https://doi.org/10.12968/bjon.2007.16.14.24328

Collins C, Rochfort A (2016) Promoting self-management and patient empowerment in primary care. Irish College of General Practitioners, Dublin 27-35. https://doi.org/10.5772/62763

Corner J, Wagland R, Glaser A, Richards M (2013) Qualitative analysis of patients' feedback from a PROMs survey of cancer patients in England. BMJ Open 3(4):3e002316. https://doi.org/10.1136/ bmjopen-2012-002316

Cotogni P, Pedrazzoli P, De Waele E, Aprile G, Stragliotto GFS, De Lorenzo F, Caccialanza R (2019) Nutritional therapy in cancer patients receiving chemoradiotherapy: should we need stronger recommendations to act for improving outcomes? J Cancer 10(18):4318-4325. https://doi.org/10.7150/jca.31611

De Smith MJ (2018) Statistical analysis handbook. A comprehensive guide to statistical concept, methods and tools. The Winchelsea Press, pp 48-165

Dobrila-Dintinjana R, Trivanovic D, Zelić M, Radić M, Dintinjana M, Petranović D, Toni V, Vukelic J, Matijasic N (2013) Nutritional support in patients with colorectal cancer during chemotherapy: does it work? Hepatogastroenterology 60(123):475-480. https:// doi.org/10.5754/hge12710

Dodd M, Janson S, Facione N, Faucett J, Froelicher ES, Humphreys J, Lee K, Miaskowski C, Puntillo K, Rankin S, Taylor D (2001) Advancing the science of symptom management. Nursing theory and concept development or analysis. J Adv Nurs 33(5):668-676

Dodd M, Miaskowski C (2000) The Pro-Self-Program: a self-care intervention program for patients receiving cancer treatment. Seminars Oncol Nurs 16(4):300-308. https://doi.org/10.1053/ sonu. 2000.16586

Drury A, Payne S, Brady AM (2017) The cost of survival: an exploration of colorectal cancer survivors' experiences of pain. Acta Oncol 56(2):205-211. https://doi.org/10.1080/02841 86X.2016.1266084

Gao WJ, Yuan CR (2011) Self-management programme for cancer patients: a literature review. Int Nurs Rev 58(3):288-295. https:// doi.org/10.1111/j.1466-7657.2011.00907.x

Gideon L (2012) Handbook of Survey Methodology for the Social Sciences. Springer Nature Switzerland AG, Basel, 1 edn. pp 15-348

Grant M, McMullen CK, Altschuler A, Mohler MJ, Hornbrook MC, Herrinton LJ, Wendel CS, Baldwin CM (2011) Gender differences in quality of life among long-term colorectal cancer survivors with ostomies. Oncol Nurs Forum 38(5):587-596. https://doi. org/10.1188/11.ONF.587-59

Gray NM, Allan JL, Murchie P, Browe S, Hall S, Hubbard G, Johnston M, Lee AJ, McKinley A, Macleod U, Presseau J, Samuel S, Wyke S, Campbell NC (2013) Developing a community-based complex intervention to improve quality of life in people with colorectal cancer: Evidence, theory and acceptability. Support Care Cancer 21:73. https://doi.org/10.1136/bmjopen-2013-00259

Guo Z, Tang H, Li H, Tan S, Feng K, Huang Y, Bu Q, Jiang W (2013) The benefits of psychosocial interventions for cancer patients undergoing radiotherapy. Health Qual Life Outcomes 11:121. https://doi.org/10.1186/1477-7525-11-121

Hammer MJ, Ercolano EA, Wright FMS, Dickson VV, Chyun D, Melkus GD (2015) Self-management for adult patients with cancer. An integrative review. Cancer Nurs 38(2):E10-E26. https:// doi.org/10.1097/NCC.0000000000000122

Harrison JD, Young JM, Preis MA, Butow PN, Solomon MJ (2009) What are the unmet supportive care needs of people with cancer? 
A systematic review. Support Care Cancer 17(8):1117-1128. https ://doi.org/10.1007/s00520-009-0615-5

Hartinger J, Veselý P, Matoušková E, Argalacsová S, Petruželka L, Netíková I (2012) Local treatment of hand-foot syndrome with uridine/thymidine: in vitro appraisal on a human keratinocyte cell line HaCaT. Sci World J 421325. https://doi. org/10.1100/2012/421325

Hébuterne X, Lemarié E, Michallet M, Beauvillain de Montreuil C, Schneider SM, Goldwasser F (2014) Prevalence of malnutrition and current use of nutrition support in patients with cancer. JPEN J Parenter Enteral Nutr 38(2):196-204. https://doi. org/10.1177/0148607113502674

Hoffmann TC, Glasziou PP, Boutron I, Milne R, Perera R, Moher D, Altman DG, Barbour V, Macdonald H, Johnston M, Lamb SE, Dixon-Woods M, McCulloch P, Wyatt JC, Chan AW, Michie S (2014) Better reporting of interventions: template for intervention description and replication (TIDieR) checklist and guide. BMJ 7(348):g1687. https://doi.org/10.1136/bmj.g1687

Howell D, Harth T, Brown J, Bennett C, Boyko S (2017) Self-management education interventions for patients with cancer: a systematic review. Support Care Cancer 25(4):1323-1355. https://doi. org/10.1007/s00520-016-3500-z

Jenniches I, Lemmen C, Cwik JC, Kusch M, Labouvie H, Scholten N, Gerlach A, Stock S, Samel C, Hagemeier A, Hellmich M, Haas P, Hallek M, Pfaff H (2020) Evaluation of a complex integrated, cross-sectoral psycho-oncological care program (isPO) a mixedmethods study protocol. BMJ Open 10(3):e034141. https://doi. org/10.1136/bmjopen-2019-034141

Jensen W, Baumann FT, Stein A, Bloch W, Bokemeyer C, De Wit M, Oechsle K (2014) Exercise training in patients with advanced gastrointestinal cancer undergoing palliative chemotherapy: a pilot study. Support Care Cancer 22(7):1797-1806. https://doi. org/10.1007/s00520-014-2139-x

Jorgensen ML, Young JM, Harrison JD, Solomon MJ (2012) Unmet supportive care needs in colorectal cancer: differences by age. Support Care Cancer 20(6):1275-1281. https://doi.org/10.1007/ s00520-011-1214-9

Kim KJ, Na YK, Hong HS (2016) Effects of progressive muscle relaxation therapy in colorectal cancer patients. West J Nurs Res 38(8):959-973. https://doi.org/10.1177/0193945916635573

Kondrup J, Rasmussen HH, Hamberg O, Stanga Z, Ad Hoc ESPEN Working Group (2003) Nutritional risk screening (NRS 2002): a new method based on an analysis of controlled clinical trials. Clin Nutr 22(3):321-336

Kreitler S (2019) Psycho-oncology for the clinician: the patient behind the disease, 1st ed. Springer, Heidelberg, New York, London, pp 29-208

Kwekkeboom K, Zhang Y, Campbell T, Coe CL, Costanzo E, Serlin RC, Ward S (2018) Randomized controlled trial of a brief cognitivebehavioral strategies intervention for the pain, fatigue, and sleep disturbance symptom cluster in advanced cancer. Psychooncology 27(12):2761-2769. https://doi.org/10.1002/pon.4883

Leitlinienprogramm Onkologie (Deutsche Krebsgesellschaft, Deutsche Krebshilfe, AWMF) S3-Leitlinie Kolorektales Karzinom, Langversion 1.1 - August 2014, AWMF Registrierungs-nummer: 021/007OL. https://www.leitlinienprogramm-onkologie.de/filea dmin/user_upload/ Downloads/Leitlinien/Kolorektales_Karzinom/ LL_KRK_Langfassung_1.1.pdf. Accessed 20 March 2016

Leitlinienprogramm Onkologie (Deutsche Krebsgesellschaft, Deutsche Krebshilfe, AWMF) S3-Guideline of the German Society for Nutritional Medicine (DGEM) in Cooperation with the DGHO, the ASORS and the AKE. Clinical Nutrition in Oncology, 2015, AWMF Registrierungsnummer: 073/006. https://www.dgem.de/sites/default/ files/PDFs/Leitlinien/-S3-Leitlinien/073-0061_S3_Klin_Ernährung _in_der_Onkologie_2015-10.pdf. Accessed 11 May 2019

Lin JX, Chen XW, Chen ZH, Huang XY, Yang JJ, Xing YF, Yin LH, Li X, Wu XY (2017) A multidisciplinary team approach for nutritional interventions conducted by specialist nurses in patients with advanced colorectal cancer undergoing chemotherapy: a clinical trial. Medicine (Baltimore) 96(26):e7373. https://doi.org/10.1097/ MD.0000000000007373

Marks JH, Myers EA, Zeger EL, Denittis AS, Gummadi M, Marks GJ (2017) Long-term outcomes by a transanal approach to total mesorectal excision for rectal cancer. Surg Endosc 31(12):5248-5257. https://doi.org/10.1007/s00464-017-5597-7

Mehnert A, Lordick F (2017) Specialized oncological nurses play a key role at the interface between medicine and psychology. Can Oncol Nurs J 27(3):304-305

Middleton RJ (2014) Meeting the psychological care needs of patients with cancer. Nurs Stand 28(21):39-45. https://doi.org/10.7748/ ns2014.01.28.21.39.e8149

Mosher CE, Winger JG, Given BA, Shahda S, Helft PR (2017) A systematic review of psychosocial interventions for colorectal cancer patients. Support Care Cancer 25(7):2349-2362. https://doi. org/10.1007/s00520-017-3693-9

Nosbusch JM, Weiss ME, Bobay KL (2011) An integrated review of the literature on challenges confronting the acute care staff nurse in discharge planning. J Clin Nurs 20(5-6):754-774. https://doi.org/1 0.1111/j.1365-2702.2010.03257.x

Ravasco P, Monteiro-Grillo I, Camilo M (2012) Individualized nutrition intervention is of major benefit to colorectal cancer patients: long-term follow-up of a randomized controlled trial of nutritional therapy. Am J Clin Nutr 96:1346-1353. https://doi.org/10.3945/ ajcn.111.018838

Ravasco P (2019) Nutrition in cancer patients. J Clin Med 8(8):1211. https://doi.org/10.3390/jcm8081211

Robert-Koch-Institut (2017) Krebs in Deutschland für 2013/2014. Zentrum für Krebsregisterdaten. GEKID, 11. Ausgabe, Berlin. https:// edoc.rki.de/bitstream/handle/176904/3270/22EwGndhBfkPkE. pdf? sequence=1\&isAllowed=y. Accessed 24 Dec 2020

Sakamoto N, Takiguchi S, Komatsu H, Okuyama T, Nakaguchi T, Kubota Y, Ito Y, Sugano K, Wada M, Akechi T (2017) Supportive care needs and psychological distress and/or quality of life in ambulatory advanced colorectal cancer patients receiving chemotherapy: a cross-sectional study. Jpn J Clin Oncol 47(12):1157-1161. https:// doi.org/10.1093/jjco/hyx152

Scott I, Del Mar C, Hoffmann T, Benett S (2017) Embedding evidencbased practice into routine clinical care. In: Hoffmann T, Bennett $\mathrm{S}$, Del Mar C (eds) Evidence-Based Practice across the Health Professions, 3rd edn. Elsevier, Australia, pp 410-424

Schlüchtermann J (2020) Betriebswirtschaft und Management im Krankenhaus. Grundlagen und Praxis. 3. Auflage, Medizinisch Wissenschaftliche Verlagsgesellschaft mbH \& Co. KG, Berlin, pp 247-257

Shun SC, Yeh KH, Liang JT, Huang J, Chen SC, Lin BR, Lee PH, Lai YH (2014) Unmet supportive care needs of patients with colorectal cancer: significant differences by type D personality. Oncol Nurs Forum 41(1):E3-11. https://doi.org/10.1188/14.ONF.E3-E11

Solheim TS, Vagnildhaug OM, Laird BJ, Balstad TR (2019) Combining optimal nutrition and exercise in a multimodal approach for patients with active cancer and risk for losing weight: rationale and practical approach. Nutrition 27(67-68):110541. https://doi.org/10.1016/j. nut.2019.06.022

Steven B, Lange L, Schulz H, Belich C (2019) Views of psychooncologists, physicians, and nurses on cancer care. A qualitative study. PLoS ONE 14(1):e0210325. https://doi.org/10.1371/journ al.pone. 0210325

Stiel S, Joppich R, Korb K, Hahnen M, Elsner F, Rossaint R, Radbruch $L$ (2009) Problems and deficits in the transition from inpatient and outpatient care of cancer patients. A qualitative analysis. Pain 23(5):510-517. https://doi.org/10.1016/j.zefq.2008.12.002

Stuhlfauth S, Melby L, Helles $\varnothing$ R (2018) Everyday life after colon cancer: the visible and invisible challenges. Cancer Nurs 41(6):E48-E57. https://doi.org/10.1097/NCC.00000000000-00506 
Tung HY, Chao TB, Lin YH, Wu SF, Lee HY, Ching CY, Hung KW, Lin TJ (2016) Depression, fatigue, and QoL in colorectal cancer patients during and after treatment. J Nurs Res 38(7):893-908. https://doi. org/10.1177/0193945916630256

Usta YY (2012) Importance of social support in cancer patients. Asian Pac J Cancer Prev 13(8):3569-3572. https://doi.org/10.7314/APJCP .2012.13.8.3569

Van Vulpen JK, Steins Bisschop CN, Velthuis MJ, May AN (2016) Effects of an exercise program in colon cancer patients undergoing chemotherapy. Med Sci Sports Exerc 48(5):767-775. https://doi. org/10.1249/MSS.0000000000000855

Waring J, Marshall F, Bishop S, Sahota O, Walker M, Currie G, Fisher R, Avery T (2014) An ethnographic study of knowledge sharing across the boundaries between care processes, services and organisations: the contributions to 'safe' hospital discharge. NIHR J Library Health Serv Delivery Res 2(29). https://doi.org/10.3310/hsdr02290
Zaner MZ (2015) A critical examination of ethics in health care and biomedical research. Voices and visions. Springer, Heidelberg, New York, London, pp 45-149

Zhanga M, Chan SW, You L, Chan Y, Wu Y, Peng L, Liu W, Zheng M (2014) The effectiveness of a self-efficacy-enhancing intervention for Chinese patients with colorectal cancer: a randomized controlled trial with 6-month follow up. Int J Nurs Stud 51(8):1083-1092. https ://doi.org/10.1016/j.ijnurstu.-2013.12.005

Zorba P, Ozdemir L (2018) The preliminary effects of massage and inhalation aromatherapy on chemotherapy-induced acute nausea and vomiting: a quasi-randomized controlled pilot trial. Cancer Nurs 41(5):359-366. https://doi.org/10.1097/NCC.0000000000000496

Publisher's Note Springer Nature remains neutral with regard to jurisdictional claims in published maps and institutional affiliations.

\section{Affiliations}

\section{Margarete Reiter ${ }^{1,2}$ (D) Michael Gerken ${ }^{3} \cdot$ Patricia Lindberg-Scharf ${ }^{4} \cdot$ Alois Fuerst $^{5}$. Gudrun Liebig-Hörl ${ }^{6}$. Olaf Ortmann ${ }^{7} \cdot$ Ingeborg Eberl $^{8} \cdot$ Sabine Bartholomeyczik ${ }^{9}$}

Michael Gerken

Michael.Gerken@klinik.uni-regensburg.de

Patricia Lindberg-Scharf

Patricia.Lindberg-Scharf@uni-regensburg.de

Alois Fuerst

afuerst@caritasstjosef.de

Gudrun Liebig-Hörl

gliebig@caritasstjosef.de

Olaf Ortmann

oortmann@ caritasstjosef.de

Ingeborg Eberl

inge.eberl@ku.de

Sabine Bartholomeyczik

Sabine.Bartholomeyczik@uni-wh.de

1 Diplom-Kauffrau, Faculty of Health, School of Nursing Science, PhD Student at the Witten/Herdecke University, Stockumer Straße 12, 58453 Witten, Germany

2 Caritas-Hospital Sankt Josef, Landshuter Straße 65, 93053 Regensburg, Germany

3 Tumor Center Regensburg-Institute of Quality Management and Health Services Research of the University of Regensburg, Coordination, Epidemiology, Am Biopark 9, 93053 Regensburg, Germany
4 Tumor Center Regensburg-Institute of Quality Management and Health Services Research of the University of Regensburg, Section Quality of Life, Am Biopark 9, 93053 Regensburg, Germany

5 Director of the Department of General and Visceral Surgery, Caritas-Hospital Sankt Josef, Landshuter Straße 65, 93053 Regensburg, Germany

6 Medical Coordinator of Colon Cancer Center, Caritas-Hospital Sankt Josef, Landshuter Straße 65, 93053 Regensburg, Germany

7 Director of the Department of Gynecology and Obstetrics, University Medical Center Regensburg, Caritas-Hospital Sankt Josef, Landshuter Straße 65, 93053 Regensburg, Germany

8 Faculty of Social Work, Catholic University of Eichstätt-Ingolstadt, Kapuzinergasse 2, 85072 Eichstätt, Germany

9 Faculty of Health, School of Nursing Science, Witten/Herdecke University, Stockumer Straße 12, 58453 Witten, Germany 